\title{
OYUNLAŞTIRMA VE ÖĞRENCİ KATILIMI: LİSANS EĞITTIMINDE BİR DURUM ÇALIŞMASI
}

\author{
Hidayet Suha YÜKSEL ${ }^{1}$, Seda CANLI ${ }^{2}$ \\ 1,2 Ankara Üniversitesi Spor Bilimleri Fakültesi, Ankara
}

\begin{abstract}
Öz: Türkiye'de üniversitelerin yaygınlaşması ile birlikte öğrenci sayısı önemli ölçüde artmış ve eğitimciler çeşitliliğin oldukça fazla olduğu gruplar ile karşı karşıya kalmaya başlamışlardır. Bu duruma kuşak farkı nedeniyle ortaya çıkan ilgi farklılıkları ve iletişim güçlükleri de eklendiğinde öğrenciler ile aynı dili konuşmak ve onların derse olan aktif katılımlarını sağlamak önemli sorunlardan birisi olmuştur. Bu bağlamda eğitim alanında öğrencilerin derse aktif katılımını sağlama noktasında çalışılan konulardan birisi de oyunlaştırmadır. Araştırmanın amacı oyunlaştııılmış derse katılan öğrencilerin deneyimlerini öğrenci katılımı kavramı çerçevesinde keşfetmektir. Bu araştırmaya 2017-2018 eğitim-öğretim yılında Ankara Üniversitesi Spor Bilimleri Fakültesi Beden Eğitimi ve Spor Öğretmenliği Bölümü 1. sınıfta okuyan ve kolay ulaşılabilir durum örneklemesi ile ölçüt örnekleme yöntemi ile seçilmiş 18 (12 kadın, 6 erkek) öğrenci gönüllü olarak katılmışır. Araştırma kapsamında eğitim bilimine giriş dersi 8 hafta boyunca oyunlaştırmaya yönelik kahoot, edmodo ve video görev mekanizmaları ile desteklenerek tasarlanmıştır. Veri kaynağı olarak yarı yapılandırılmış bireysel görüşmeler ve yansıtıcı günlük kullanılmıştır. Verilerin analizinde içerik analizi yapılmış ve bu kapsamda kodlama işlemi tamamlandıktan sonra ortak özellikleri yansıtan temalara ulaşılmıştır. Araştırmada oyunlaştırmaya dayalı müdahalenin derse yansımaları dört tema altında sunulmuştur. Ortaya çıkan ilk tema oyunlaştırmanın temel amacına ilişkin vurguyu yansıtan öğrenci katılımı teması olmuştur. İkinci ve üçüncü temada öğrenci katılımını destekleyen baskın oyunlaştırma bileşenleri olarak rekabet ortamı ve ödül temalarına yer verilmiştir. Son temada ise bu süreçte derse katılımın devamlılığ için risk oluşturan unsurlar öğrenci katılımının engelleri teması altında sunulmuştur. Sonuç olarak oyunlaştırmaya yönelik müdahalenin kısa vadede öğrencilerin derse aktif katılımlarını sağlamada faydalı olabileceği ve rekabet ortamı ile ödülün bu devamlılığın sağlanmasında oyunlaştırılmış derse yansıyan ana unsurlar olduğu keşfedilmiştir. Aktif katılımın uzun vadede devam edebilmesinin önündeki engellerin ise dışsal ödül bileşenlerinin ön plana çıması, kaynak sınırlılıkları ve teknik problemler olduğu anlaşılmıştır.
\end{abstract}

Anahtar Kelimeler: Derse Katılım, Eğitimde Yenilikler, Oyunlaştırma, Öğretmen Yetiştirme, Yükseköğretim

\section{GAMIFICATION AND STUDENT ENGAGEMENT: A CASE STUDY IN UNDERGRADUATE EDUCATION}

\begin{abstract}
The number of students along with the rise of universities in Turkey has increased dramatically and educators have started to interact with student groups where diversity is quite high. When differences of interest and communication difficulties due to generation difference are added to this situation, speaking the same language with students and ensuring their active participation in the course have been an important issue. In this context, one of the subjects studied on the point of providing active participation of the students in the field of education is the gamification. The aim of the study is to explore the experiences of students participating in a gamified learning environment within the framework of the concept of student engagement. In this study, 18 (12 female, 6 male) students in the 1st year of Physical Education and Sports Teaching Department of Ankara University Faculty of Sport Sciences participated voluntarily in 2017-2018 academic year. In the sample selection, convenience sampling and criterion sampling were used. Within the scope of the research, the introduction to educational science course was designed by gamification with the structure provided by kahoot and edmodo systems for 8 weeks. Semi-structured individual interviews and reflective daily were used as data sources. Content analysis was performed in the analysis of the data and after the coding process, the themes reflecting the common characteristics were reached. The reflections of the gamification-based intervention on the course were presented under four themes. The first theme was the student engagement theme that reflects students' experiences with the gamification course. In the second and third themes, competition and reward themes were included as dominant gamification components that support student participation. In this process, the risk factors for the continuity of student engagement were presented under the theme of obstacles of student engagement. As a result, it has been discovered
\end{abstract}


that the intervention towards gamification is useful in ensuring the engagement of the students in the short term, and that competition and reward are the main elements reflected in the gamified course in ensuring this continuity. Barriers to participation in the long term have been the concentration on external award components, resource limitations and technical problems.

Keywords: Educational Innovations, Teacher Training, Higher Education, Gamification, Engagement,

\section{GíRiş}

Yeni nesillerin günümüzdeki teknolojik araçları daha yoğun kullanmaları gerçeği ile birlikte artık derslerde telefonları ile meşgul olan öğrencilere daha fazla rastlayabilirsiniz. Bu noktada teknolojiyi sorunun kaynağı olarak gördüğünüzde çözüm için telefonu yasaklamak ya da derslerde kapattırmak basit bir yol olabilir fakat öğrencilerin neden bu kadar dijital teknoloji ile meşgul olduklarını anlamaya çalışmak daha kalıcı çözümlerin bulunmasına yol açabilir. Teknolojiyi çözümün bir parçası olarak değerlendirmek isteyen eğitimcilerin bu anlamda eğitim ortamlarında çeşitli teknolojileri kullandığı ve bu teknolojiler üzerine araştırmaların yoğunlaştığ1 görülmektedir (Poondej ve Lerdpornkulrat, 2016; Tsay, Kofinas ve Luo, 2018; Yapıcı ve Karakoyun, 2017). Bu noktada yapılan çalışmalardan önce, yeni neslin teknoloji ile bütünleşmesini anlama noktasında bazı kavramlar aydınlatıcı olabilir. Öncelikle bu konuya ilişkin Prensky'nin (2001a) yaklaşımına bakıldığında, dijital yerliler ve dijital göçmenler kavramları ile karşılaşmaktayız. Prensky’e (2001a) göre dijital yerli olarak adlandırılan yeni nesil; günümüz teknolojileri ile iç içe büyümüş, bu teknolojileri rahatlıkla kavrayan ve kullanan kişilerden oluşurken, dijital göçmenler olarak tanımlanan nesil ise; teknolojiyi sonradan öğrenmek durumunda kalan kişilerden oluşmaktadır. Dijital göçmenlerin dijital yerlilere uygun bir öğrenme ortamı oluşturabilmeleri için onlarla aynı dili kullanabilmeleri gerekmektedir. Aynı dili kullanabilmenin yollarından birisi de oyunlaştırmadır. Bu anlamda oyunlaştırmayı tanımlamadan önce kavram içerisinde geçen oyun ifadesine değinmek gerekirse; bahsi geçen dijital oyun, katılımcıların kuralları tanımlanmış yapay bir mücadele içerisinde oldukları ve ölçülebilir sonuçları olan bir sistemdir (Salen, Tekinbas ve Zimmerman, 2004). Bu tür dijital oyunlarda, sisteme, oyunculara, gerçekliğin özet bir formunun yansıtılmasına, farklı zorluk seviyelerine, kurallara, etkileşime, sayılabilir sonuçlara ve duygusal tepkiye gerek vardır (Salen, Tekinbas ve Zimmerman, 2004). Bu noktada kısaca ifade edilen dijital oyunu anladıktan sonra oyunlaştırma kavramına değinmek gerekirse, oyunlaştırma dijital oyunlara ait özelliklerin normalde oyunsallık içermeyen durum ve içeriklerde kullanılmasını ifade eden bir kavramdır. Kapp (2012) tarafından yapılan tanıma göre ise; oyunlaştırma "insanları bağlama, motive etme, ögrenmeyi destekleme ve problem çözme amacıyla oyuna dayalı mekaniklerin, estetiğin ve oyun düşüncesinin kullanımı" şeklinde ifade edilmiştir.

Ortak yönleri üzerinden değerlendirildiğinde birçok oyunlaştırma sistemi gerçek bir ortama puanlar, seviyeler, liderlik tablosu, başarılar ya da rozetler ekleyerek, insanların bu ödülleri kazanmak için mevcut duruma daha çok bağlanmasını amaçlamaktadır (Nicholsan, 2015, s.1). İnsanların davranışlarını değiştirmek için yüzyıllardır kullanılan ödül kavramı oyunlaştırma için de anahtar kavramlardan biridir. Bu bağlamda öğrencinin motivasyonunu ve derse aktif katılımını artırma noktasında oyunlaştırılmış bir öğrenme çevresinin kurulabilmesi için bu çevrenin oyuna dayalı olması, seviyeleri, puanları, zaman sınırını ve rozetleri içeren bir yazılımın olması, öğrencilerin oyun içinde olduklarını düşünmeleri için sıralamanın belirtilmesi, eyleme geçmek için motive olmaları ve öğrenmeyi desteklemek için kullanılıyor olması gerekmektedir (Kapp, 2013). Oyunlaştırmaya ve özellikle oyunlaştırmanın bileşenlerine yönelik farklı yaklaşımların olduğu görülmektedir. Bu çalışmada Nicholsan 
(2012) tarafından adlandırılan BLAP (rozet, seviye, başarı, puanlar) oyunlaştırması ya da ödüle dayalı oyunlaştırma yaklaşımı tercih edilmiştir. Bu yaklaşım kısa sürede değişim istendiğinde elverişli olan ve gerçek bir durumda rozetlerin, liderlik tablosunun, başarıların ve puanların kullanıldığı oyunlaştırmayı ifade etmektedir (Nicholsan, 2015, s.2). Ödüle dayalı oyunlaştırma sadece dışsal motivasyona odaklandığı için uzun süreli değişimleri gerektiren içsel motivasyonun sağlanmasında zararlı olabilir (Deci ve Ryan, 2001). Bu noktada uzun vadeli değişim hedeflerinde dışsal motivasyon unsurları ile birlikte içsel motivasyonun desteklenmesi için oyunlaştırılan sistemin nihai olarak kullanıcı da özerklik, yeterlik ve ilişkililik hissini sağlamayı amaçlaması gerekmektedir (Deci ve Ryan, 2002). Bu amaca ulaşmak için oyunlaştırmanın anlamlı olmasına ihtiyaç vardır. Anlamlı kavramı Mezirow'un (1991) dönüşümsel öğrenme modelinde bahsettiği inançların dönüşümüne katkısı olan deneyimleri ifade etmektedir. Bu bağlamda eğitim ortamında oyunlaştırmaya dayalı uygulamaların dışsal motivasyon unsurlarıyla birlikte, içsel motivasyonu destekleyici bir yapıyı da sağlaması gerekmektedir.

Türkiye' de üniversitelerin hızla artışı ile birlikte üniversiteye giren öğrenci sayısı önemli ölçüde artmış ve eğitimciler çeşitliliğin oldukça fazla olduğu gruplar ile karşı karşıya kalmaya başlamışlardır. Bu duruma kuşak farkı nedeniyle ortaya çıkan ilgi farklılıkları ve iletişim güçlükleri de eklendiğinde öğrenciler ile aynı dili konuşmak ve onların derse olan ilgilerini artırmak önemli konulardan birisi olmuştur. Birçok öğrenci tarafından geleneksel dersler sıkıcı ve verimsiz olarak algılanmaktadır (Dicheva, Dichev, Agre ve Angelova, 2015). Bu noktada öğrencilerin öğrenme sürecine aktif katılımlarını sağlamak için birçok farklı yaklaşım eğitim alanındaki araştırmacılar tarafından anlaşılmaya çalışılmaktadır (Gilboy, Heinerichs ve Pazzaglia, 2015; Henrie, Halverson ve Graham, 2015; Tsay, Kofinas ve Luo, 2018). Eğitim alanında öğrencilerin derse aktif katılımını ve öğrenme isteğini artırmak için çalışılan konulardan birisi de oyunlaştırmadır. Eğitimsel oyunlaştırma dijital oyuna ilişkin mekanik ve unsurların eğitimsel bağlamda sanal öğrenme ortamlarından da destek alarak kullanılmasıdır (Al-Azawi, Al-Faliti ve Al-Blushi, 2016). Teknolojik ilerlemeler ile birlikte birçok eğitimci oyunlaştırmaya yönelik Quizizz, Socrative ve Quizalize gibi online platformları dersin içerisinde öğrencilerin motivasyonlarını ve katılımlarını artırmak için kullanmaktadır (Rahman, Ahmad ve Hashim, 2018). Bu konuda hassas olunması gereken konu diğer tüm teknoloji desteklerinde olduğu gibi bu yaklaşımında etkili bir öğrenme çevresinde bütünün bir parçası olarak uygulanması olacaktır.

\section{Öğrenci Katılımı}

Teknolojideki hızlı ilerleme, değişen dünya ve insan ile birlikte eğitim-öğretim kavramları üzerine sorgulamaların arttığı bir dönemde yaşamaktayız. Artık odak kavramın öğrenme olduğu günümüzde öğrencilerden, öğrenme iştiyakına sahip olmaları ve bu sorumluluğu üstlenmeleri beklenmektedir. Bu bağlamda eğitimde oyunlaştırmanın amacı öğrencinin öğrenme iştiyakını ortaya çıkarmak ve derse katılımını artırmak için oyun gibi düşünmesini ve eğlenmesini desteklemektir. Öğrenci katılımı kavramı öğrenme sürecine katılan bireylerin, dikkat, ilgi ve tutku ile aktif katılımlarını sağlama ile ilgili olan bir kavramdır (Reeve, 2012). Güçlü bir motivasyon ve yüksek görev bağlılığı başarılı öğrenme deneyimlerini kolaylaştırır (Davis ve McPartland, 2012). Katılım kavramı öğrenme etkinliklerine dahil olmaya ve bu etkinlikleri tamamlamaya istekli olmayı ifade etmektedir (Skinner ve Belmont, 1993). Eğitimcilerin öğrencilerin derse katılımda gözlemledikleri problemlerin üstesinden gelmek için çözüm yollarını araştırmaya ve yeni yollar denemeye ihtiyaçları vardır. Elbette öğrencilerin dersten 
uzaklaşmalarına sebep olan birçok farklı faktör olabilir fakat derse yeniden katılmaları için onları dersten uzaklaştıran birçok nedenin üstesinden gelebilecek ortak ilgi alanları da mevcuttur. Oyun, ödül sistemi, sosyal medya gibi yenilikler dijital yerli olarak ifade edilen ya da kuşak çalışmalarında farklı sınıflandırmalarla özellikleri belirtilen bu neslin yeniden derse katılımlarını sağlama noktasında ortak ilgi alanlarını yansıtabilir. Yapılan bazı çalışmalar öğrenci katılımını öğrenmenin gerçekleşmesi için en önemli faktörlerden birisi olarak göstermektedir (Faiella ve Ricciardi, 2015; Poondej ve Lerdpornkulrat, 2016; Tan, 2018). Tersi durum olan öğrencinin dersten uzaklaşması durumu ise dersin amaçları ve öğrenme çıktıları noktasında arzu edilmeyen sonuçlara neden olarak verimli öğrenmeye engel olmaktadır (Archambault, Janosz, Fallu ve Pagani, 2009; Finn ve Zimmer, 2012; Salamonson, Andrew ve Everett, 2009). Oyunlaştırma ve öğrenci katılımı bağlamında yapılan çalışmalar oyunlaştırılan öğrenme çevresinin arzu edilen sonuçları elde edebilmek için etkili olduğunu göstermektedir (Brigham, 2015; Caton \& Greenhill, 2014; Cheong, Filippou, \& Cheong, 2014; Leaning, 2015). Oyunlaştırma ile sağlanan etkileşimli öğrenme deneyimi sayesinde, öğrencinin derse katılımı ile ilgili sorunların üstesinden gelinebilir, derin düşünme ve yansıtma için firsatlar sunulabilir, olumlu yönde davranış değişimi sağlanabilir ve otantik bir uygulama ortamı yaratılabilir (Kapp, 2013). Bu bağlamda araştırmanın amacı oyunlaştırılmış bir öğrenme çevresine katılan öğrencilerin deneyimlerini öğrenci katılımı kavramı çerçevesinde keşfetmektir. Bu noktada araştırmada şu sorulara cevap aranmıştır:

1) Oyunlaştırılmış ders ortamına katılan öğrencilerin deneyimleri nasıldır?

2) Öğrenci katılımını destekleyen oyunlaştırma bileşenleri nelerdir?

3) Öğrenci katılımının sürmesinde oyunlaştırmaya ilişkin aşılması gereken engeller nelerdir?

\section{YÖNTEM}

\section{Araştırma Deseni ve Katılımcılar}

Öğrencilerin oyunlaştırmaya ilişkin deneyimlerini daha ayrıntılı keşfedebilmek amacıyla araştırmada nitel araştırma yaklaşımı ve durum çalışması deseni kullanılmıştır. Durum çalışması, araştırmacının bir programı, olayı, aktiviteyi, süreci veya bir ya da daha fazla kişiyi derinlemesine araştırdığ araştırmalarda bir araştırma olgusunun derinlemesine anlaşılması ve sürecin takibi amaçlanmaktadır (Vogt ve ark., 2014, s:426). Durum çalışmaları amaca, çalışılan disipline ve araştırma yaklaşımına göre sınıflandırılmıştır. Bu araştırmada benimsenen açıklayıcı durum çalışmaları bir şeyi açıklamayı ya da neden-sonuç ilişkisini bulmayı hedeflemektedir (SavinBaden ve Major, 2013, s.156). Bazı araştırmacılar nitel araştırmaların neden-sonuç ilişkisini belirleyemeyeceğine inansa da Yin'e (2011, s.23) göre nitel araştırmalar bu ilişkiyi belirleyebilir.

Bu araştırmaya 2017-2018 eğitim-öğretim yılında Ankara Üniversitesi Spor Bilimleri Fakültesi Beden Eğitimi ve Spor Öğretmenliği Bölümü 1. sınıfta okuyan ve kolay ulaşılabilir durum örneklemesi ile ölçüt örnekleme yöntemi ile seçilmiş 18 (12 kadın, 6 erkek) öğrenci gönüllü olarak katılmıştır. Katılımcılar araştırmacılar ile aynı okulda yer alan ve birinci araştırmacının dersine katılan öğrenciler olması sebebiyle kolay ulaşılabilir durumdadır. Bunun dışında katılımcıların belirlenmesinde ölçüt örneklemesi yöntemi kullanılmış ve oyunlaştırmaya ilişkin görevlerin tümünü yerine getirmiş olmak ölçüt olarak kabul edilmiştir. Bu doğrultuda 
görevlerin tamamında yer almayan öğrenciler derse ilişkin oyunlaştırma sürecine katılmış fakat araştırma sürecine dahil edilmemişlerdir.

\section{Uygulama Süreci ve Bağlam}

Araştırma kapsamında eğitim bilimine giriş dersi 8 hafta boyunca oyunlaştırmaya yönelik kahoot, edmodo ve video görev mekanizmaları ile desteklenerek tasarlanmıştır. Her dersin sonunda o günkü dersin konularına ilişkin sorulardan oluşan sınavlar kahoot üzerinden gerçekleştirilmiştir. Kahoot çevrimiçi olarak çoktan seçmeli sınavların, anketlerin ya da tartışmaların yapılabildiği, bir Web 2.0 aracıdır. Öğretmen tarafından hazırlanan sınavlara öğrenciler cep telefonu, tablet ya da bilgisayarları ile üretilen kodu girmek suretiyle sınıf ortamında eş zamanlı olarak online sınava katılmışlardır. Kahoot sınavlarında katılımcılar hem doğru cevaba hem de cevaplama süresine göre puan elde ederek sıralanmışlardır. Bunun dışında kahoot sınavları yapıldıktan sonra ders edmodo üzerinden görevler ile sanal ortama taşınmıştır. Oyunlaştırma mekanizması büyük ölçüde edmodo üzerinden sağlanmıştır. Edmodo öğretmenler, öğrenciler ve veliler için geliştirilmiş bir "sosyal öğrenme platformu" sitesidir. Edmodo ile öğretmenler çevrim içi sınıflar oluşturarak grup kodları ile öğrencileri davet etmektedir. Aynı zamanda bu sistem öğrencilere ödevler verilerek online ortamda incelenip puan verilmesine, rozetlerin oluşturulmasına firsat veren bir alt yapıya sahiptir. Zaten görevlerin ve puanlamanın yapılabildiği edmodo ayrıca çeşitli rozetler ve sanal puanların verilmesi için alt yapı sağlamıştır. Ayrıca haftalık alınan puanlar sonucu oluşan sınıf sıralaması da edmodo üzerinden paylaşılmıştır. Kahoot üzerinden sınav puanını zaten hemen öğrenen öğrenci ayrıca verilen görevlere ilişkin de aldığı puanı aynı gün öğrenmiştir. Oyunlaştırma bileşenleri ile ilgili alan yazında farklı sınıflandırmalar bulunmaktadır. Bu araştırmada Nicholsan (2012) tarafından adlandırılan BLAP oyunlaştırması ya da ödüle dayalı oyunlaştırma yaklaşımı tercih edilmiştir. Bu yaklaşım kısa sürede değişim istendiğinde elverişli olan ve gerçek bir durumda rozetler, seviyeler/liderlik tablosu, başarılar ve puanların kullanıldığı oyunlaştırmayı ifade etmektedir (Nicholsan, 2015, s.2). Oyunlaştırma tasarımına ilişkin genel yap1 şekil 1'de sunulmuştur.

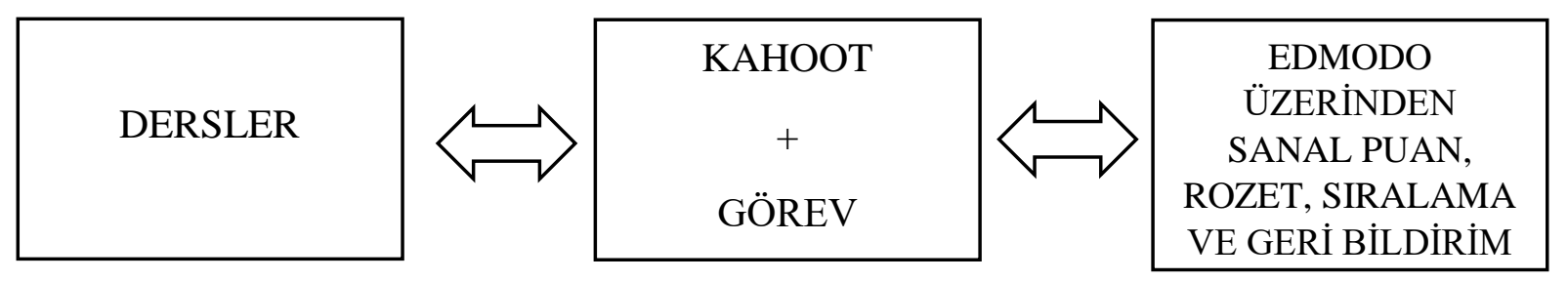

Şekil 1. Derse İlişkin Oyunlaştırmanın Genel Yapısı

Buradaki sanal puanların, rozetlerin, kahoot sınav puanlarının gerçekte nasıl kullanılacağına ilişkin de uygulama öncesi bilgilendirme yapılmıştır (Tablo 1). Oyunlaştırmanın doğası gereği bu sürece katılım için teşvik edici bir puanlama sistemi konulmuş fakat katılım zorunlu tutulmamıştır. Ayrıca katılmayan öğrenciler klasik sınavları üzerinden herhangi bir kısıtlama olmadan değerlendirilmişlerdir. 


\section{Tablo 1. Puanlama Sistemi}

\begin{tabular}{|c|c|}
\hline Ders Sonu Kahoot Sinavi (8 sinav) & $\begin{array}{l}\text { - Altın madalya: Hepsi doğru veya } 1 \\
\text { yanlış (5 puan) } \\
\text { - Gümüş madalya: } 2 \text { yanlış (4 puan) } \\
\text { - Bronz madalya: } 3 \text { yanlış (3 puan) }\end{array}$ \\
\hline Edmodo Üzerinden Görevler (6 görev) & $\begin{array}{l}\text { - Altın madalya: } 100-90 \text { sanal puan } \\
\text { (10 puan) } \\
\text { - Gümüs madalya: } 89-80 \text { sanal puan } \\
\text { (7 puan) } \\
\text { - Bronz Madalya: } 79-70 \text { sanal puan (5 } \\
\text { puan) }\end{array}$ \\
\hline $\begin{array}{l}\text { Puan Aralıkları } \\
\text { FINISH } \\
\end{array}$ & $\begin{array}{l}\text { - } \quad \text { 85-100 sanal puan }=25 \mathrm{ek} \text { puan } \\
\text { - } 70-84 \text { sanal puan }=20 \mathrm{ek} \text { puan } \\
\text { - } 55-69 \text { sanal puan }=15 \mathrm{ek} \text { puan } \\
\text { - } 40-54 \text { sanal puan }=10 \mathrm{ek} \text { puan } \\
\text { - } 25-39 \text { sanal puan }=5 \mathrm{ek} \text { puan } \\
\text { - } 10-24 \text { sanal puan }=3 \mathrm{ek} \text { puan }\end{array}$ \\
\hline Rozetler & \\
\hline
\end{tabular}

\section{Araştırmacıların Rolleri}

$\mathrm{Bu}$ çalışmada araştırmacılar farklı roller üstlenmişlerdir. Birinci araştırmacı dersin uygulayıcısı konumunda olan, oyunlaştırma tasarımını yapan ve puanlamayı gerçekleştiren kişidir. Araştırmacı olarak daha önce farklı yaş gruplarında beden eğitimi derslerinde ve ders dışı etkinliklerde teknoloji destekli aktif oyun üzerine araştırmalar yapmıştır (Yuksel, 2019; Yüksel, 2018; Yüksel ve Tuncel, 2017). Teknolojinin üniversite düzeyinde de derslere entegre edilmesinde oyunlaştırmanın önemli bir alternatif olabileceği düşüncesiyle bu çalışmayı dizayn etmiştir. Bunun dışında oyunlaştırılmış derslere ilişkin gözlemlerini günlük tutarak bilgisayar ortamına aktarmıştır. Öğrencilerin öğretmenleri ile görüşürken düşüncelerini rahat yansıtamayabileceği düşüncesiyle birinci araştırmacı görüşmelere dahil olmamıştır. Araştırmanın ikinci ismi, görev videolarının çekilmesinde, puanlama sonucunda sıralamanın güncellenmesinde ve yaşanan sorunlarda birebir iletişim kurulmasında aktif rol almıştır. Ayrıca bireysel görüşmeleri gerçekleştirmiştir.

\section{Veri Kaynakları}

Veri kaynağı olarak bireysel görüşme ve günlük kullanılmıştır. Bireysel görüşmeler sırasında araştırmacılar tarafından hazırlanan yarı yapılandırılmış görüşme formu tercih edilmiştir. $\mathrm{Bu}$ formda oyunlaştırmaya yönelik müdahalenin farklı açılardan yansımalarını içeren sorular sorulmuştur. Görüşmeler ses kayıt cihazı kullanılarak gerçekleştirilmiştir. Verilerin 
toplanmasında birincil kaynak olan yarı yapılandırılmış görüşmelerin dışında yansıtıcı günlüklere yer verilmiştir. Dersin uygulayıcısı o günkü derse ilişkin önemli anekdotları, öğrencilerin derse katılımını yansıtan davranışları ve buna ilişkin yardımcı olabilecek şekilde eğlenme, keyif alma, sıkılma, ilgi duyma, odaklanma gibi durumları yansıtan öğrencilerin tepkilerini ders bittikten sonra aynı gün içinde bilgisayar ortamına aktarmıştır. Bu yolla derste olup bitenlere ilişkin tüm ayrıntılar betimlenmeye çalışılmış ve görüşmeler ile elde edilen verilerin paralellik gösterip göstermediği anlaşılmaya çalışılmıştır.

\section{Verilerin Analizi}

Verilerin analizinde içerik analiz yöntemi kullanılmıştır. İçerik analizi örüntüleri, temaları, varsayımları ve anlamları tanımlamak için özel bir materyalin dikkatli, detaylı ve sistematik şekilde incelenmesi ve yorumlanmasıdır (Berg, Lune ve Lune, 2014, s:182). Bireysel görüşmeler ve günlükler yoluyla toplanan tüm veriler bilgisayar ortamına aktarıldıktan sonra öncelikle okunmuş ve bazı notlar alınmıştır. Sonrasında sırasıyla araştırmacılar tarafından açık kodlama yoluyla her bir verinin anlamını yakalayacak şekilde etiketleme işlemi ve birleştirici fikirleri ortaya koyan temaların bulunması ve isimlendirilmesi yapılmıştır.

\section{İnandırıcılık}

Araştırmanın niteliğini sağlama noktasında birçok araştırmacı uygun olduğunu düşündüğü farklı kavramlar geliştirmişlerdir (Guba ve Lincoln, 1994; Major ve Savin-Baden, 2012). Bu araştırmanın inandırıcılığını sağlamak için süreç bakımından; veri çeşitlemesi, grupla uzun süre bağ kurma ve tüm sürecin ayrıntılı olarak yazılması stratejileri; ürün bakımından ise, araştırmacının rolünü belirtme, çalışılan bağlamın özelliklerini betimleme ve doğrudan alıntılara yer verme stratejileri izlenmiştir (Savin-Baden ve Major, 2013, s:476-480).

\section{BULGULAR}

Araştırmada oyunlaştırmaya dayalı müdahalenin derse yansımaları dört tema altında sunulmuştur. Ortaya çıkan ilk tema oyunlaştırmanın temel amacına ilişkin öğrenci deneyimlerini yansıtan öğrenci katılımı teması olmuştur. İkinci ve üçüncü temada derse katılımı destekleyen baskın oyunlaştırma bileşenleri olarak rekabet ortamı ve ödül temalarına yer verilmiştir. Son temada ise bu süreçte derse katılımın devamlılığı için risk oluşturan unsurlar ise öğrenci katılımının engelleri teması altında sunulmuştur. Temalara ilişkin genel yapı şekil 2'de sunulmuşstur. 


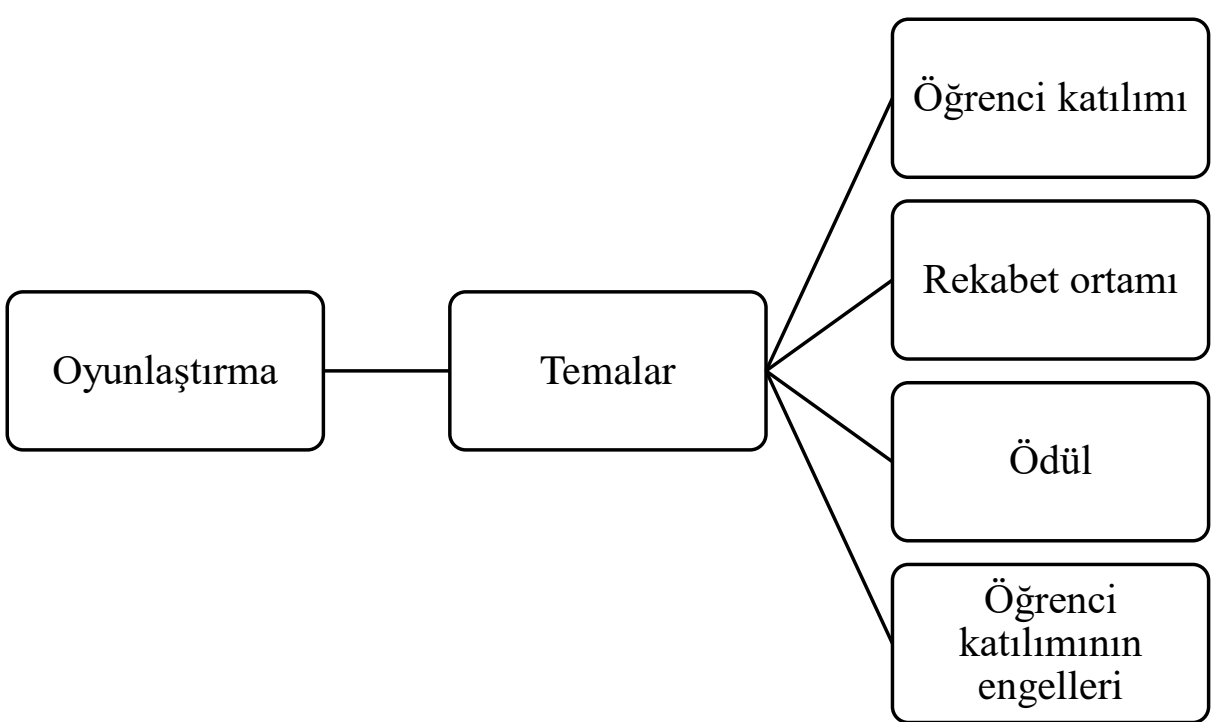

\section{Şekil 2. Oyunlaştırma sürecine ilişkin bulgular}

\section{Öğrenci Katılımı}

Tüm müdahalelerin nihai amacı derse olan ilgi ve katılımı artırmaktır. Bu noktada sürece dahil olan öğrencilerin oyunlaştırılmış ortam ile birlikte derse olan ilgi ve katılımlarının arttığını ifade etmesi bu çabanın karşılık bulduğunu göstermektedir. Bu bağlamda derse ilgi ve katılımı sağlayan özellikler, görev düşüncesi, sürekli değerlendirmenin olması, girmezsem bir şeyler kaçırırım düşüncesi, ders içi uygulamalar, ekstra puan alma isteği, sürekli çalışmak zorunda bırakması gibi durumlar olmuştur. Bu konuda verilen görevler ile birlikte dersin okul dışına da taşınmasını Demet diğer derslerle de kıyaslayarak, "Kıyasladığım durumda ders daha ilgi çekici oluyor çünkü bu görevler sürekli o dersi düşünmemizi gerektiriyor. Hani gün içerisinde otobüste giderken bile 'bu görevde ne yapsam acaba' diye bir düşünce halinde oluyoruz." sözleriyle ifade etmiştir. Aynı konuda görev ile birlikte dersin kapsamındaki farklılı̆̆ Kenan ise; "Diğer işlediğimiz derslerde genelde dersi saat içerisinde işleyip bırakıyoruz. Onun dişında ekstra çalışmalar kendimiz yaparsak oluyor ama bu derste verilen görevlerle ders dişında da ders bir nevi devam ediyor gibi oluyor, daha ciddi hazırlanıyoruz" sözleriyle ifade etmiştir. Görevlerin derse yansımasını Sude ise "Mesela bu edmodo üzerinden yaptığımız uygulamaları diğer derslerde de uygularsak daha faydalı olacağını düşünüyorum. Bizi dersten kopartmayan bir çalışma çünkü" sözleriyle görevlerin ders ile bağın devam etmesinde önemli olduğunu vurgulamıştır. Ders ile iç içe olma durumunu Ayşe ise; "Öncelikle sorumluluk bilincine sahip insanların üzerinde bir bask yaratıyor. Hani bunu yapmalıyım, bitirmeliyim, daha güzel nasıl yapabilirim diye. O anlamda bizi dersten koparmadı sürekli iç içe olduk." sözleriyle ifade etmiştir. Bazı öğrencilerin ifadelerine yansıyan bu durum verilen görevlerin öğrencinin dersi daha fazla düşünmesinde ve aktif katılımın sağlanmasında önemli bir rol olabileceğini ortaya koymaktadır.

Öğrencilere göre bu derse katılımı sağlayan diğer unsurlar; görevler ve ders sonrası yapılan sınavlardan dolayı öğrencilerde oluşan derse girmezsem bir şeyler kaçırırım düşüncesi olmuştur. Emre bu hususu; "Önceden dersin adını bile tam bilmiyordum. Birkaç hafta gelmedim bile. Edmodo ve kahoot'u duyunca derse gelmeye başladım." sözleriyle, Meryem ise; "Kahoot sinavı var diye sürekli derse geliyorduk. Derse katılım çok fazlaydı" sözleriyle bu durumu ifade etmişlerdir. Derse gelinmediğinde bir şeyleri kaçırırım düşüncesini ise Asım: "Dersler gelme isteğini artırıyor. Bu dersi kaçırınca kaybedeceğim bir şey oluyor ama diğer 
teorik derslerde sorun yok. Derse gitme otur oku..." sözleriyle belirtirken aynı hususu Naz şu sözlerle ifade etmiştir:

Mesela bu derste bir gün gelmediğimde bir şeyleri kaçırdığımı düşünüyorum ama başka derste öyle olmuyor. Mesela başka bir dersin notunu alabilirim ya da arkadaşlarıma sorarım ama bu derste çok farklı şeyler işliyoruz. Uygulamada yani arkadaşlarım birini gösterse diğerini gösteremeyebilir. O yüzden orada bulunmak benim için avantajlı olduğu için hiçbir dersi kaçırmamaya çalışıyorum.

Genel olarak öğrencilerin derse katılımını destekleyen son durum sürecin görev tamamlamayı ve hazırlıklı olmayı gerektiren yapısı olmuştur. Bu durumu Açelya "Evet mesela ilk haftalarda normal bir ders olarak giriyorduk, sonra durum değişti. Edmodo ve kahoot uygulamalarl ile birlikte otomatik olarak hazırlıklı gelmeye başlıyorsun" sözleriyle, Sude, "Verilen ödevler derslerle alakalı olduğu için hafta içinde de en son işlediğimiz konu hakkında görevi yaptığımda derse de hazırlıklı gitmiş oluyorduk" sözleriyle, Ebrar ise, "Bir görevi tamamlıyoruz sonra yine çalışmak zorunda kalıyoruz. Yani bizi sürekli çalışmaya itiyor. Hani böyle vize de çalışırı finalde çalışırı diye yatmıyoruz. Bir göz gezdirmek zorunda kalıyoruz şimdi sinavımı var diye. Gelmeden önce dolmuşta bile baklyorum." sözleriyle bu durumun derse yansımasını ifade etmişlerdir. Son olarak araştırmacının günlüğüne yansıyan şu ifadelerde derse katılım noktasında öğrenci görüşlerine benzerlik göstermektedir:

Bu dersin doğası sıkıcı. Öğrenci açısından baktığımda da sıkılmalarına hak veriyorum. Çok yoğun bir içerik kısa zamanda veriliyor. Oyunlaştırma ile birlikte belki bazen yine sıkılıyorlar ama ders sonrası yarışma var diye daha çok dinlemek ve derse aktif katılmak durumunda kalıyorlar (Öğretmen günlüğü, 14.11.2017).

Bu kısımda genel olarak oyunlaştırma sürecinin derse katılım anlamında destekleyici özellikleri ifade edildi. Sonraki bölümlerde bu aktif katılımın sağlanmasında oyunlaştırmaya ilişkin ön plana çıkan bileşenlerin ayrıntılarına yer verilecektir.

\section{Rekabet Ortamı}

Rekabet ortamı oyunlaştırmanın temelinde yer bulan oyun düşüncesinin karşılık bulmasıyla gerçekleşmiştir. Bu bağlamda bu ortamı destekleyen unsurlar, rekabete bağlı daha iyi olma çabası ve sıralama olmuştur. Bunun dişında rekabet ortamını daha çok hissettiren destek ise bazı öğrencilere göre kahoot sınavları olmuştur. Bu noktada yarışma içerisinde olduklarını Açelya "Dersler içerisinde bir tek bu derste bu kadar araştırma yapıyoruz. Birde puanlama olduğu için rekabet var, yüksek almak için çabalıyoruz. Mesela yarış oyunu olur ya. Kahoot ve edmodo ile yarış içerisinde gibi hissediyoruz." sözleriyle ifade ederken ortama ilişkin düşünceleri Esra benzer şekilde "Daha çok rekabet oluştu. Hani şu ödevi de yapmayım aman boş ver demedim. Daha çok yapmaya çalıştım." sözleriyle ifade etmiştir. Bu rekabet ortamının performansa ilişkin yansımaları konusunda da bazı öğrencilerin olumlu düşüncelere sahip olduğu anlaşılmıştır. Bu konuda Kenan "Derste rekabet ortamı gelişmeye başladı. Birbirimiz ile yarışlyoruz ve bu durum bizim performansımıza olumlu anlamda yansıyor" derken, aynı konuda Pelin beden eğitimi ve spor öğretmenliği bölümünde okuyan öğrencilerin spor geçmişiyle de ilişkilendirerek düşüncelerini "Biz sporcu insanları ve bireysel ya da takım sporlarl yapıyoruz. Böyle bir yarışma ruhu hepimizde var. O hırs hepimizde var. Dolayısiyla aramızdaki tatl rekabet ve çekişme başarıya götürür diye inanıyorum." sözleriyle aktarmıştır. Rekabete bağlı daha az hata yapıp daha iyi derece elde etme çabasını Ebrar "Sürekli birbirimizi geçme durumundayız. Sınıfımızın durumu bence gayet iyi. Herkes rekabet içinde, sınavlarda 
en fazla 1 veya 2 yanlış çıkıyor. Şimdi hatasız oynamaya çalışıyoruz" sözleriyle, Ayşe ise "Başkalarlyla yarışmak zorluyor. Onunda üstesinden gelmek için hemen bu konuyu tekrar edip haftaya ön sıralarda yer almam lazım deyip çaba gösteriyorum.” sözleriyle yansıtmışlardır.

Bunun dışında oyunlaştırma tasarımında rekabeti daha çok hissettiren uygulama ise öğrencilerin birçoğuna göre kahoot olmuştur. Aynı anda yarışın başlaması, süreye karşı mücadele ve bitiminde hemen sıralama olması gibi hususlar daha çok rekabeti hissettirmiştir. Bu konuyu Duygu "Kahoot uygulamasında biraz daha rekabet gibisinden çekişme olduğu için o hoşuma gidiyor." sözleriyle, Hakan ise "Kahoot uygulamasında da diğerlerini geçme hırsı devreye girdiği için o ilgimi çekiyor." sözleriyle yansıtmışlardır. Kahoot uygulamasında daha fazla rekabet hissetme nedenlerini Kenan "İ̧sleyiş kısmında açıkça söylemek gerekirse en çok hoşuma giden kahoot uygulaması oldu. Zamanla yarıştığımız, sonucunu direkt aldı̆̆ımız ve daha canlı bir rekabet olduğu için ve arkadaşlarımızla hep beraber aynı ortamda gerçekleştiği için bana daha güzel geldi." sözleriyle özetlemiştir. Bu anlamda bulgular oyunlaştırmanın temelinde olan yarışma ve buna bağlı rekabetin derste karşılık bulduğunu ve öğrenciler tarafindan olumlu karşılandığını ortaya koymaktadır. Bu uygulamanın derse yansıması öğretmen günlüğüne de anekdotlarla birlikte yazılmıştır.

Kahoot sınavına ilk kez bir eğitim sırasında girdiğimde yaşattığı heyecanı görünce derslerimde kullanmaya karar vermiştim. Derste kendi yaşadığım heyecanın benzerini öğrencilerinde yaşadıklarını gördüm. Yarışmaya çok alışıklar ve bu uygulama tam onlara göre (Öğretmen günlüğü, 28.11.2017).

\section{Ödül}

Oyunlaştırmanın temel bileşenlerini sağlayan en belirgin unsurlardan birisi de çeşitli ödüller veriyor olmasıdır. Bu ödül yapısı genellikle sanal puanlar ve rozetler yoluyla sağlanmaktadır. Derse ilişkin tasarımda da ödüle ilişkin puan ve rozetlerin öğrencilerin derse katılımlarında olumlu yansımaları olduğu ve bu ödüllere ilişkin geri bildirimleri hızlı almanın da önemli olduğu elde edilen bulgulardan ortaya çıkmıştır. Puanların ve rozetlerin öğrencileri daha çok çaba sarf etmeye teşvik ettiğini Açelya "Illk ödevden altın madalya rozeti aldım mesela. Bu benim daha çok motive olup daha yüksek almam gerekir diye düşünmemi sağladı." cümlesiyle ifade ederken tersi bir durumda olup ilk görevde madalya rozeti alamayan Demet "ilk başta mesela puanımın yetersiz olması ya da madalya alamamam biraz daha azmimi artırdl." cümlesiyle ifade etmiştir. Bu durumun teşvik edici olduğunu Esra, Mehmet, Sude ve Hakan'da "ekstra puan olması bizi teşvik etti." cümlesiyle aktarmışlardır.

Ekstra puanın teşvik edici yönlerinin dışında bu ödüllerin acaba ne kazanacağım diye merak uyandırıp heyecanlandırması da sürece katılımı destekleyen diğer yönü olmuştur. Bu anlamda ne kazanılacağının merak edilmesi durumunu Duygu "Hangi madalyayı alacă̆ım gibi düşünmek keyifli oluyor.” sözleriyle, Ebrar "Hani ödevden kaynaklı bir şey değil ama her seferinde elimden geldiğince bir şeyler yapıp sonucu beklemek bile güzel oluyor acaba kaç puan alacağım diye düşünmek bile merak uyandırıyor." sözleriyle, benzer durumu Pelin ise "Rozetlerin olması bir kere başlı başına heyecan uyandıran bir uygulama oldu. Rozetler geldiğinde ya da herhangi bir şekilde sonuç açıklandığında, telefona maille geldiğinde çok heyecanlanıyordum." sözleriyle ifade etmişlerdir. Bu anlamda ödül ve puan gibi uygulamaların oyunlaştırma sürecine önemli katkılarından birisi merak uyandırması olmuştur.

Oyunlaştırma sürecinde ödül sisteminin ortaya koyduğu belki en önemli katkı oyun gibi düşündürtmesi olmuştur. Bu noktada bu tür ödüllerin oyundaymış gibi hissettirdiğini Naz, 
"Mesela edmoda uygulamasındaki rozetler oyundaymış gibi hissettiriyor. Çünkü belli bir amaç var, seviye atlamak gibi, sonucunda kazanacă̆ım bir şey var. Ödevlerden aldığımız puanlar da bu şekilde sonraki göreve hazırlıyor. Kısıtll sürede olması tıpkı bir oyuna benziyor." sözleriyle, Emre "Mesela ilk bronz madalya aldım. Mutlu olup seviniyorsun yani yaşın büyükte olsa. Oyun gibi oluyor. Mesela aldı̆̆ımız puan, sıralama bunlar oyun havasına sokuyor." sözleriyle, Kenan ise "Görev sonunda puanlar açılıp dereceler oluşturulduğunda veya rozetler falan devreye girdiğinde oyun gibi gelmeye başladı.” sözleriyle belirtmişlerdir.

Oyunlaştırılmış derste ödüllere ilişsin bu yansımaların dışında önemli bir konu da bu kapsamda yapılan değerlendirmenin hızlı yapılması ve puan ya da rozet olarak geri bildirimlerin hemen verilmesidir. Geri bildirimlerin hızlı verilmesinin olumlu yansımalarını Ebrar, "Edmodo da ödevi attığımızda hocanın hemen baklyor ve değerlendiriyor olması güzel" sözleriyle ifade ederken, bu durumu Sude ' Ödevleri attığımızda hemen bakılıyor, değerlendiriliyor ve bununla ilgili düzeltme veriliyor. Bu da yararl oluyor'” sözleriyle, Eylül ise "Anında puan veriyor ve bizi sıralamaya sokuyor. Bu çok hoşuma gidiyor ve heyecanla bekliyorum” sözleriyle ifade etmişlerdir. Bu anlamda oyunlaştırma sürecinin önemli bileşenlerinden biri olan hızlı geri bildirimin süreçte karşılık bulduğu ve olumlu yansımaların olduğu bulgulardan anlaşılmıştır.

\section{Öğrenci Katılımının Engelleri}

$\mathrm{Bu}$ bölümde oyunlaştırma sürecinde öğrencilerin derse katılımının devam etmesine engel olabilecek durumlara ve öğrenciler tarafindan dile getirilen beklentilere yer verilmiştir. Öncelikle sürecin oyunlaştırmaya ilişkin bileşenleri olarak görev, rekabet ve ödül öğrenciler tarafindan eğlenceli bulunmuştur. Fakat oyunlaştırılmış derslerdeki temel bileşenler dışsal motivasyon unsurları oldukları için uzun vadede derse katılımı sağlamada olumsuz bir durum da oluşturabilir. Bu noktada öğrencilerin hoşuna giden hususlar incelendiğinde çoğunlukla dışsal kaynaklı olduğu anlaşılmıştır. Bu duruma bazı örnekler şu şekilde verilebilir:

Duygu: Kahoot oyununda ilk 5 sıralama falan olduğu için daha çekişmeli. Hoşuma gidiyor. Hakan: Rekabet olduğu için daha çok zevk veriyor. Kahoot uygulamasında da yarıştı̆̆ımız için onlar eğlenceli geliyor.

Hamza: Kahoot biraz daha eğlenceli bana göre. Çünkü hani sınıf ortamında yarışmak keyifli oluyor.

Ayşe: Sonradan bu sanal puanlar gerçek puana katılacağı için beni çok mutlu etti yani.

Yukarıda örneklerini gördügüumüz durumlar, dışsal motivasyona bağlı eğlence durumunu yansıtmaktadır. Bu durum dışsal motivasyon sağlayıcı özellikler ilgi çekmemeye başladığı anda derse katılım açısından problemlerin yaşanabileceği ihtimalini ortaya çıkarmaktadır. Kısa sürede başarı elde etmek için bu unsurlar fayda sağlasa da uzun vadede bu sürecin içsel motivasyonu desteklemesi ve öğrencilerin yeni şeyler öğrenmenin ve başarmanın keyifli yönlerinin farkına varması gerekmektedir. Bu anlamda sadece dışsal ödüle dayalı oyunlaştırma bileşenleri ile süreci devam ettirmek öğrencilerin derse katılımlarının sürmesinde engel durumuna düşebilir.

Bunun dışında oyunlaştırma sürecinde öğrencilerin derse aktif katılımının devam etmesini zorlaştırabilecek bazı teknik aksaklıklar yaşanmıştır. Bu aksaklıkların en önemlisi sınıf içerisinde internete dayalı yapılan sınavların zaman zaman öğrencilerin internetlerinin çekmemesi nedeniyle zorluklar çıkarmasıdır. Bu konuya ilişkin zorluğu Naz, Kenan, Pelin ve Ebrar, "Internetle ilgili sorunlar yaşadık." diyerek ifade etmişlerdir. Bu durumu dersi öğretmeni ise günlüğüne, "Okulun kablosuz ă̆ ya da bölge de bazı hatların iyi çekmemesi 
özellikle ders sonu sınavlarda bazen sorun çıkarıyor. Heyecanla sınavı bekleyen öğrenciler için bu tür sorunlar heves kırıcı olabiliyor" şeklinde yansitmıştır. Bunun dişında oyunlaştırma süreci hem ders içerisinde hem de ders dışında akıllı telefon, tablet ya da bilgisayar olmasını zorunlu kılmaktadır. Her ne kadar günümüzde bu cihazlar yaygın olarak kullanılsa da herkesin aynı imkanlara sahip olamaması bu noktada derse katılımın önünde engel olabilir. Bu durumu Demet, "Mesela derste kahoot uygulamasindan sinav oluyoruz. Telefonu akill telefon olmazsa bu uygulamaya katılamayabiliyor." sözleriyle, Ebrar ise "Görevler sadece teknoloji odaklı oluyor. Bu imkanlar olmayanlar görevleri tamamlamakta zorlanıyor." ş̧eklinde ifade etmişlerdir.

Öğrenci katılımının devamlılığı için yukarıda belirtilen problemler için tedbir alınmasının yanı sıra sürecin daha verimli olması için öğrencilerin verdiği önerilerde yardımcı olabilir. $\mathrm{Bu}$ noktada Duygu geri bildirimlerin puan ya da rozetin dişında herkes tarafindan yorumlanabilecek şekilde olursa daha iyi olabileceğini, "Görevlerden sonra yorum yapılabilir. Bu bence çok daha faydalı olabilir. Her bireyin kendi yorumunu okuması güzel olur." sözleriyle belirtirken, benzer hususu Kenan "Görevleri tamamladıktan sonra ögretmenimizin puan dışında yorum belirtmesi da hoş olurdu bence" sözleriyle belirtmiştir. Bunun dışında oyunlaştırma tasarımına ve verilen görevlere ilişkin de öğrencilerin önerileri olmuştur. $\mathrm{Bu}$ süreçte oyunlaştırma farklı uygulamaların tasarlanması ile sağlanmaya çalışılmıştır. Bu hususta Esra, tüm etkinliklerin tek bir uygulamada birleşmesinin daha iyi olabileceğini, Ayşe, görevlerin daha fazla grup çalışmaları gerektirecek şekilde olabileceğini, Naz görevlerin sona erme süreleri yaklaşırken geri sayım eklentisinin olumlu etki bırakabileceğini ve Pelin ise video görevlerin dışında canlı yayın ile birlikte görevlerin sunulabileceğini belirtmişlerdir. Oyunlaştırma sürecinde bu hususlarında dikkate alınması derse katılımın engellerini aşmada yardımcı olabilir.

\section{TARTIŞMA VE SONUÇ}

$\mathrm{Bu}$ araştırma kapsamında oyunlaştırılmış ders ortamına katılan lisans öğrencilerinin deneyimleri öğrenci katılımı kavramı çerçevesinde keşfedilmiştir. Oyunlaştırma tasarımlarına ilişkin kullanılacak bileşenlere ve uygulama şekillerine ilişkin farklı yaklaşımlar bulunmaktadır. Bu çalışmada Nicholsan (2012) tarafından adlandırılan BLAP oyunlaştırması ya da ödüle dayalı oyunlaştırma yaklaşımı tercih edilmiştir. Bu yaklaşım kısa sürede değişim istendiğinde elverişli olan ve gerçek bir durumda rozetler, seviyeler/liderlik tablosu, başarılar ve puanların kullanıldığı oyunlaştırmayı ifade etmektedir (Nicholsan, 2015, s.2). Lister (2015) oyunlaştırılmış öğrenme çevrelerinde yaygın olarak kullanılan ortak bileşenlerin puan, rozet, başarı durumları, liderlik sıralaması ve seviye olduğunu belirtmiştir. Bu anlamda çalışmada kullanılan BLAP oyunlaştırması bileşenlerinin büyük ölçüde yaygın olarak kullanılan bileşenlere karşılık geldiği söylenebilir. $\mathrm{Bu}$ bileşenler ile yapılandırılan oyunlaştırma kapsamında çalışmada öğrenci katılım kavramı çerçevesinde bulgular incelenmeye çalışılmıştır. Bu kapsamda müdahale ile birlikte derse katılıma ilişkin olumlu yönler, bu olumlu yönleri sağlayan oyunlaştırma özellikleri ve derse katılımın sürdürülmesinde engel teşkil edebilecek hususlar değerlendirilmiştir. Bu müdahalenin amacı öğrenme sürecine katılan bireylerin, dikkat ve ilgi ile derse aktif katılımını sağlamak olmuştur. Bu çerçevede bu amacı temellendiren kavram öğrenci katılımı kavramıdır. Derse katılım çerçevesinde oyunlaştırma bağlamında yapılan bazı çalışmalar öğrencilerin katılımını sağlamada bu tür müdahalelerin verimli olabileceğini ortaya koymaktadır (Bicen ve Karakoyun, 2018; Poondej ve Lerdpornkulrat, 2016; Tsay, Kofinas ve Luo, 2018). Bu hususta dikkat edilmesi gereken 
hususlar oyunlaştırmanın anlamlı olması ve araştırma yapılan bağlama özgü şekilde tasarlanmasıdır. Faiella ve Ricciardi (2015) oyunlaştırmaya ilişkin literatürü incelediği çalışmasında oyun bileşenlerinin akıllıca, stratejik ve uygun şekilde kullanılmasının öğrencinin aktif katılımını ve motivasyonu sağladığını belirtmiş̧lerdir.

Çalışmada ortaya çıkan ilk bulgular öğrenci katılımı teması altında sunulmuştur. Bu temada sunulan bulgular dersin nihai amacı olan ilgi ve katılımı sağlama noktasında oyunlaştırma sürecinin olumlu yansımaları olduğu şeklindedir. Bu bağlamda öğrenci katılımını sağlayan özellikler, görev düşüncesi, sürekli değerlendirmenin olması, girmezsem bir şeyler kaçırırım düşüncesi, ders içi uygulamalar ve ekstra puan alma isteği gibi hususlar olmuştur. Özelliklerden bağımsız olarak derse aktif katılım noktasında oyunlaştırmaya yönelik müdahalelerin olumlu sonuçları olduğuna ilişkin çalışmalar bulunmaktadır (Chapman ve Rich, 2018; Glowacki, Kriukova ve Avshenyuk, 2018; Meşe ve Dursun, 2018; Poondej ve Lerdpornkulrat, 2016; Rahman, Ahmad ve Hashim, 2018). Çalışmamızda öğrenci katılımını sağlama noktasındaki önemli gelişmeler oyunlaştırmanın derse aktif katılımı sağlama noktasında yardımcı olduğunu göstermektedir. Yine derse aktif katılım bağlamında oyunlaştırmaya yönelik öğrenci görüşlerinin incelendiği araştırmalarda; oyunlaştırmanın ilgi çektiği (Yıldırım ve Demir, 2016), eğlenceyi artırdığı (Hitcsen ve Tulloch, 2018; Muntean, 2011), sıkıcı görevlerden zevk almayı sağladığ1 (Hanus ve Fox, 2015) ve genel olarak öğrencilerin süreçte yer almaktan memnuniyet duymalarını sağladığı (Cheong, Filipou ve Cheong, 2014) sonuçlarına ulaşılmıştır. Bu noktada ilgi çekme, eğlenceli bulma, oyun içerisinde hissettirdiği için görev gibi düşünülmemesi ve öğrencilerin süreçten memnun olmaları araştırmamızın sonuçları ile paralellik göstermektedir.

Oyunlaştırma ile birlikte derse aktif katılımı sağlamada destekleyici unsurlardan birisi rekabet ortamı olmuştur. $\mathrm{Bu}$ anlamda oyunlaştırma sürecinin rekabet getiren yapısından öğrencilerin memnun olduklarını gösteren çalışmalar (Iosup ve Epema, 2014; Meşe ve Dursun, 2018) ile birlikte memnun olmadıklarını ve rahatsızlık duyduklarını gösteren (Chapman ve Rich, 2018; Domínguez ve ark., 2013) çalışmalar da vardır. Bu çalışma özelinde rekabet oyunlaştırmanın temelinde yer bulan oyun düşüncesinin karşılık bulmasıyla gerçekleşmiştir ve sürecin bu yönü öğrencileri memnun eden bir özellik olarak ortaya çıkmıştır. Oyunların yapısal özelliklerinden bir tanesi de rekabettir ve bu özellik heyecan duyulmasına neden olmaktadır (Prensky, 2001b). Oyunlaştırmada rekabeti sağlayan bazı unsurlar rozetler, liderlik sıralaması ve seviyelerdir (Dicheva, Dichev, Agre ve Angelova, 2015). Bu bağlamda araştırmada oyunlaştırma sürecinde bu unsurların hepsi kullanılmıştır fakat ön plana çıkan özellikler daha iyi olma çabası ve sıralama olmuştur. Bu noktada Cheong, Filippou ve Cheong (2014) yapmış oldukları çalışmada rekabeti sağlayan yapının daha çok liderlik tablosu olduğu sonucuna ulaşmışlardır. Benzer şekilde Meşe ve Dursun'un (2018) yapmış oldukları çalışmada da rekabet ortamını sağlayan oyunlaştırma bileşenlerinden birinin seviye sistemi olduğu sonucuna ulaşılmıştır. Bu bulgular çalışmamızda ortaya çıkan bulgular ile örtüşmektedir. Yapıcı rekabet ortamının aktif katılımı sağlamadaki rolünü oyunlaştırma mekaniklerinde aramak gerekebilir. Werbach ve Hunter'a (2012) göre eylemin devam etmesini ve öğrencinin aktif katılımının sürmesini sağlayan oyun mekanikleri zorluk seviyesi, rekabet, iş birliği, geribildirim ve ödüldür. Oyun dinamikleri, mekanikleri ve bileşenlerinin incelendiği bir başka çalışmada rekabetin heyecanlı olmayı sağlaması olumlu yönü olarak çıkarken, dersten uzaklaştırması olumsuz yönü olarak ortaya çıkmıştır (Yıldırım, 2017). Araştırmamızda katılımcıların rekabet durumunun olumsuz yönlerinden hiç bahsetmeme nedeni spor geçmişlerinden dolayı yarışma ve rekabet içeren ortamlara alışkın olmalarından kaynaklı olabilir. 
Oyunlaştırma ile birlikte derse aktif katılımı sağlamada destekleyici unsurlardan bir diğeri ise ödül olmuştur. Oyunlaştırma sürecinde ödül vermeyi sağlayan bileşenler, puanlar, ilerleme çubukları, sanal ödüller ya da rozetler olarak belirlenmiştir (Lee ve Hammer, 2011). Araştırma kapsamında gerçekleşen ödüle dayalı oyunlaştırma tasarımında bu bileşenler içerisinde yer alan sanal puanlar ve sanal madalyalar kullanılmıştır. Aynı zamanda bu sanal puanların gerçekte derse ekstra puan kazandırmasını sağlayan bir yapı oluşturulmuştur. Araştırmalar oyunlaştırmaya ilişkin tasarım prensipleri ile dışsal ödül sağlayıcı bileşenlerin kombinasyonunun öğrencilerin öğrenme sürecine daha aktif katılımında motivasyon kaynağ olabileceğini ortaya koymaktadır (Iosup ve Epema, 2014; Landers ve Callan, 2011; Poondej ve Lerdpornkulrat, 2016). Araştırmamızda kısa sürede öğrencilerin aktif katılımına ilişkin olumlu yansımalar bu çalışmalar ile paralellik göstermektedir. Rozet, puanlar, seviye ve sanal ödül gibi bazı oyun bileşenleri dışsal ödüllere hizmet ederken; sosyal grafik, takımlar ve içerik açma gibi bileşenler kişisel olarak önemli anlamlarla öğrenciyi buluşturduğu için içsel motivasyona hizmet etmektedir (Banfield ve Wilkerson, 2014). Bu bilgiyi araştırma sonuçları ile ilişkilendirdiğimizde elde edilen bulgular bu çalışma kapsamında yapılan oyunlaştırma tasarımının kısa vadede derse aktif katılımı desteklediğini göstermektedir fakat bu noktada dişsal motivasyon sağlayan ödüllerin kısa vadede olumlu sonuçlar getirse bile uzun vadede olumsuz sonuçlara sebep olabilmesi anlamlı oyunlaştırma ihtiyacını ortaya çıkarmaktadır (Nicholsan, 2015). Bu araştırmada ödüle dayalı sistemin derse aktif katılımı sağlaması anlamlı oyunlaştırma bakımından bir işaret olsa da anlamlı oyunlaştırma için daha fazlasına ihtiyaç vardır. Nicholson'a (2013) göre anlamlı oyunlaştırma için oyunlaştırmaya ilişkin bileşenlerin kullanıcı merkezli olması ve ödüllerin sadece gerçekten ihtiyaç olduğunda verilmesi bir yol olabilir. Ayrıca oyunlaştırma bileşenlerinin Deci ve Ryan'ın (1985) içsel motivasyona ilişkin teorilerinde ortaya koydukları ilişkili olma, yeterlik ve özerklik ihtiyaçlarını karşılaması içsel motivasyonun sürmesini sağlayabilir. Bu konuda araştırmanın daha uzunlamasına yapılması bu noktadaki öğrenci davranışlarını anlamak bakımından faydalı olacaktır.

Araştırmanın son teması öğrencilerin derse aktif katılımlarının engelleri üzerine olmuştur. Esasında en önemli engel yukarıda bahsi geçen dışsal motivasyon unsurları ile içsel motivasyon unsurlarının birleşememesi sonucu öğrencilerde uzun vadede içsel motivasyonun zarar görmesidir. Bu çalışma özelinde öğrencilerin keyif aldıkları hususların çoğunlukla dışsal ödül kaynaklı olması derse aktif katılımın uzun süre devam etmesinde engel olabilir. Bu noktada oyunlaştırma sürecinde dişsal ödüllerin uzun vadede öğrencilerin öğrenme sürecini olumsuz etkilediğine ilişkin çalışmalar bulunmaktadır (Deci, Koestner ve Tyan, 2001; Lawley, 2012). Bu noktada oyunlaştırmaya ilişkin bileşenler öğrenciler tarafından eğlenceli bulunmuştur fakat oyunlaştırılmış derslerdeki temel bileşenler dışsal ödül unsurları oldukları için uzun vadede derse katılımı sağlamada olumsuz bir durum da oluşturabilir. Uzun vadeli derse aktif katılım için içsel motivasyonu da destekleyen oyunlaştırma bileşenlerinin çeşitlendirilmesi ve öğrencinin daha çok karar alabildiği ve bireyselleştirebileceği tasarımların geliştirilmesi gerekmektedir. Öğrencilerinin derse aktif katılımının bir diğer önemli engeli teknik konularda yaşanan problemler olmuştur. Oyunlaştırma mekanizmaları teknoloji odaklı ve internete dayalı çalışan sistemler olduğu için okullarda bu konularda yaşanan problemler öğrencilerin sürece ilişkin heyecanının devam etmesinde engel olabilir. Bu konuda öğretmenlerin bakış açısıyla oyunlaştırmanın benimsenmesinin sağlayıcıları ve engellerinin incelendiği çalışmada, kaynakların sınırlılığı, öğrenci isteksizliği, konu seçimi ve sınıf dinamikleri dört ana engel olarak ifade edilmiştir (Sanchez-Mena ve Marti-Parreno, 2017). Bir başka çalışmada oyunlaştırmaya dayalı eğitim ortamında ortaya çıkan altı ana engelden bir tanesi teknik 
problemler olmuştur (Demirbilek ve Tamer, 2010). Çalışmalarda ortaya çıkan ana problemlerden kaynakların sınırlılığ sürecimizde de yaşanmıştır. Bu konular derse aktif katılım sürecinin devamı için planlanıp çözülmesi gereken problemlerden birkaçıdır.

Sonuç olarak oyunlaştırmaya yönelik müdahalenin kısa vadede öğrencilerin derse aktif katılımlarını sağlamada faydalı olabileceği, rekabet ortamı ve ödüllerin ise katılım devamlılığının sağlanmasında oyunlaştııılmış sınıfa yansıyan ana unsurlar olduğu keşfedilmiştir. Sürecin uzun vadede devam edebilmesinin önündeki engeller ise; dışsal ödül bileşenlerinin ön plana çıkması, kaynak sınırlılıkları ve teknik problemler olduğu anlaşılmıştır.

\section{Sınırlılıklar ve Öneriler}

Farklı araştırmalar için aydınlatıcı olması açısından araştırmanın sınırlılıkları şu şekilde ifade edilebilir. Öncelikle bu araştırma ödüle dayalı oyunlaştırmanın bileşenleri temel alınarak tasarlanmıştır. $\mathrm{Bu}$ anlamda çalışma tasarım sürecinde kullanılan rozet, seviyeler/liderlik tablosu, başarı ve puan bileşenleri ile sınırlıdır. Bunun dışında oyunlaştırma sürecinde Edmodo ve Kahoot uygulamaları kullanılarak süreç tasarlanmıştır. Bu yönüyle de çalışma Edmodo ve Kahoot'un sunabildiği alt yapı ile sınırlıdır.

Çıkan sonuçlar ve araştırmanın sınırlılıkları dikkate alınarak öncelikle tasarıma ilişkin olarak öğrencide daha uzun vadede değişim için sosyal etkileşimin, grup çalışmalarının ve öğrencilerin karar verme süreçlerine katılma imkanlarının daha fazla olduğu oyunlaştırma tasarımlarının yapılması ve araştırılması önerilmektedir. Bunun dışında Alsawaier (2018) yapmış olduğu derleme çalışmasında oyunlaştırmanın teori ve pratiği arasında bir boşluk olduğunu ve oyunlaştırılmış tasarımlara rehberlik edecek çalışmaların çok sınırlı olduğu sonucuna ulaşmıştır. Bu noktada teorik bilginin pratikte karşılık bulabileceği oyunlaştırma tasarımlarının nasıl olması gerektiğine ilişkin araştırmaların yapılması önerilmektedir. Son olarak kaynak sınırlılıklarının ve teknik problemlerin sorun teşkil etmemesi için daha önceden özellikle internetin çekim gücü ile ilgili teknik alt yapının kontrol edilmesi, problem varsa çözülmesi ve sonrasında böyle bir sürece başlanması önerilmektedir.

\section{KAYNAKLAR}

Al-Azawi, R., Al-Faliti, F., Al-Blushi, M. (2016). Educational gamification vs. game based learning: Comparative study. International Journal of Innovation, Management and Technology, 7(4), 132-136.

Alsawaier, R. S. (2018). The effect of gamification on motivation and engagement. The International Journal of Information and Learning Technology, 35(1), 56-79.

Archambault, I., Janosz, M., Fallu, J. S., Pagani, L. S. (2009). Student engagement and its relationship with early high school dropout. Journal of adolescence, 32(3), 651-670.

Banfield, J., Wilkerson, B. (2014). Increasing student intrinsic motivation and self-efficacy through gamification pedagogy. Contemporary Issues in Education Research, 7(4), 291-298.

Berg, B. L., Lune, H. (2014). Pearson New International Edition: Qualitative Research Methods for the Social Sciences. Pearson.

Bicen, H., Kocakoyun, S. (2018). Perceptions of Students for Gamification Approach: Kahoot as a Case Study. International Journal of Emerging Technologies in Learning (iJET), 13(02), 72-93.

Brigham, T. J. (2015). An introduction to gamification: adding game elements for engagement. Medical reference services quarterly, 34(4), 471-480. 
Caton, H., Greenhill, D. (2014). Rewards and penalties: A gamification approach for increasing attendance and engagement in an undergraduate computing module. International Journal of Game-Based Learning (IJGBL), 4(3), 1-12.

Chapman, J. R., \& Rich, P. J. (2018). Does educational gamification improve students' motivation? If so, which game elements work best?. Journal of Education for Business, 93(7), 315-322.

Cheong, C., Filippou, J., Cheong, F. (2014). Towards the gamification of learning: Investigating student perceptions of game elements. Journal of Information Systems Education, 25(3), 233-244.

Creswell, J. W., Creswell, J. D. (2017). Research design: Qualitative, quantitative, and mixed methods approaches. Sage publications.

Davis, M. H., McPartland, J. M. (2012). High school reform and student engagement. In Handbook of research on student engagement (pp. 515-539). Springer, Boston, MA.

Deci, E. L., \& Ryan, R. M. (1985). The general causality orientations scale: Self-determination in personality. Journal of research in personality, 19(2), 109-134.

Deci, E. L., Ryan, R. (2002). Handbook of Self--Determination Research (pp. 227-268). Rochester: University of Rochester Press. Deci, EL, \& Ryan.

Deci, E. L., Koestner, R., Ryan, R. M. (2001). Extrinsic rewards and intrinsic motivation in education: Reconsidered once again. Review of educational research, 71(1), 1-27.

Demirbilek, M., Tamer, S. L. (2010). Math teachers' perspectives on using educational computer games in math education. Procedia-Social and Behavioral Sciences, 9, 709-716.

Dicheva, D., Dichev, C., Agre, G., Angelova, G. (2015). Gamification in education: A systematic mapping study. Journal of Educational Technology \& Society, 18(3).

DomíNguez, A., Saenz-De-Navarrete, J., De-Marcos, L., FernáNdez-Sanz, L., PagéS, C., MartíNez-HerráIz, J. J. (2013). Gamifying learning experiences: Practical implications and outcomes. Computers \& Education, 63, 380392.

Faiella, F., Ricciardi, M. (2015). Gamification and learning: a review of issues and research. Journal of e-Learning and Knowledge Society, 11(3).

Finn, J. D., Zimmer, K. S. (2012). Student engagement: What is it? Why does it matter?. In Handbook of research on student engagement (pp. 97-131). Springer, Boston, MA.

Gilboy, M. B., Heinerichs, S., Pazzaglia, G. (2015). Enhancing student engagement using the flipped classroom. Journal of nutrition education and behavior, 47(1), 109-114.

Głowacki, J., Kriukova, Y., Avshenyuk, N. (2018). GAMIFICATION IN HIGHER EDUCATION: EXPERIENCE OF POLAND AND UKRAINE. Advanced Education, 5(10), 105-110.

Guba, E. G., Lincoln, Y. S. (1994). Competing paradigms in qualitative research. Handbook of qualitative research, 2(163-194), 105.

Hanus, M. D., Fox, J. (2015). Assessing the effects of gamification in the classroom: A longitudinal study on intrinsic motivation, social comparison, satisfaction, effort, and academic performance. Computers \& Education, 80, 152-161.

Henrie, C. R., Halverson, L. R., Graham, C. R. (2015). Measuring student engagement in technology-mediated learning: A review. Computers \& Education, 90, 36-53.

Hitchens, M., Tulloch, R. (2018). A gamification design for the classroom. Interactive Technology and Smart Education, 15(1), 28-45. 
Iosup, A., Epema, D. (2014, March). An experience report on using gamification in technical higher education. In Proceedings of the 45th ACM technical symposium on Computer science education (pp. 27-32). ACM.

Kapp, K. M. (2012). The gamification of learning and instruction: game-based methods and strategies for training and education. John Wiley \& Sons.

Kapp, K. M. (2013). The gamification of learning and instruction fieldbook: Ideas into practice. John Wiley \& Sons.

Landers, R. N., Callan, R. C. (2011). Casual social games as serious games: The psychology of gamification in undergraduate education and employee training. In Serious games and edutainment applications (pp. 399-423). Springer, London.

Lawley, E. (2012). Games as an alternate lens for design. Interactions, 19(4), 16-17.

Leaning, M. (2015). A study of the use of games and gamification to enhance student engagement, experience and achievement on a theory-based course of an undergraduate media degree. Journal of Media Practice, 16(2), 155170.

Lee, J. J., Hammer, J. (2011). Gamification in education: What, how, why bother?. Academic exchange quarterly, 15(2), 146.

Lister, M. C. (2015). Gamification: The effect on student motivation and performance at the post-secondary level. Issues and Trends in Educational Technology, 3(2), 1-22.

Major, C.H., Savin-Baden, M. (2010). An Introduction to Qualitative Research Synthesis: Managing The Information Explosion in Social Science Research. London: Routledge.

Meşe, C., Dursun, Ö. Ö. (2018). Oyunlaştırma Bileşenlerinin Duygu, İlgi ve Çevrimiçi Katılıma Etkisi. EĞİTiM VE BILIM , 43(196), 67-95.

Mezirow, J. (1991). Transformative dimensions of adult learning. Jossey-Bass, 350 Sansome Street, San Francisco, CA 94104-1310.

Muntean, C. I. (2011). Raising engagement in e-learning through gamification. In Proc. 6th International Conference on Virtual Learning ICVL.

Nicholson, S. (2012). Strategies for meaningful gamification: Concepts behind transformative play and participatory museums. Meaningful Play.

Nicholson, S. (2015). A recipe for meaningful gamification. Gamification in education and business (pp. 1-20). Springer, Cham.

Poondej, C., Lerdpornkulrat, T. (2016). The development of gamified learning activities to increase student engagement in learning. Australian Educational Computing, 31(2).

Prensky, M. (2001a). Digital natives, digital immigrants part 1. On the horizon, 9(5), 1-6.

Prensky, M. (2001b). Fun, play and games: What makes games engaging. Digital game-based learning, 5(1), 531.

Rahman, R. A., Ahmad, S., Hashim, U. R. (2018). The effectiveness of gamification technique for higher education students engagement in polytechnic Muadzam Shah Pahang, Malaysia. International Journal of Educational Technology in Higher Education, 15(1), 41.

Reeve, J. (2012). A self-determination theory perspective on student engagement Handbook of research on student engagement (pp. 149-172): Springer.

Salamonson, Y., Andrew, S., Everett, B. (2009). Academic engagement and disengagement as predictors of performance in pathophysiology among nursing students. 
Salen, K., Tekinbaş, K. S., Zimmerman, E. (2004). Rules of play: Game design fundamentals. MIT press.

Sánchez Mena, A. A., \& Martí Parreño, J. (2017). Drivers and barriers to adopting gamification: teachers' perspectives. The Electronic Journal of e-Learning, 15(5), 434-443.

Savin-Baden, M., Major, C. H. (2013). Qualitative research: The essential guide to theory and practice. Routledge.

Scott Nicholson, S. (2013). Two paths to motivation through game design elements: reward-based gamification and meaningful gamification. iConference 2013 Proceedings (pp. 671-672). doi:10.9776/13313

Skinner, E. A., Belmont, M. J. (1993). Motivation in the classroom: Reciprocal effects of teacher behavior and student engagement across the school year. Journal of educational psychology, 85(4), 571.

Tan, Y.L.L. (2018). Meaningful gamification and students' motivation: A strategy for scaffolding reading material. Online Learning, 22(2), 141-155. doi:10.24059/olj.v22i2.1167

Tsay, C. H. H., Kofinas, A., \& Luo, J. (2018). Enhancing student learning experience with technology-mediated gamification: An empirical study. Computers \& Education, 121, 1-17.

Vogt, W. P., Gardner, D. C., Haeffele, L. M., Vogt, E. R. (2014). Selecting the right analyses for your data: Quantitative, qualitative, and mixed methods. Guilford Publications.

Werbach, K., Hunter, D. (2012). The gamification toolkit. Dynamics, mechanics and components for the win. Pennsylvania: Wharton Digital Press.

Yapıcı, İ. Ü., \& Karakoyun, F. Biyoloji Öğretiminde Oyunlaştırma: Kahoot Uygulaması Örneği. Turkish Online Journal of Qualitative Inquiry, 8(4), 396-414.

Yıldırım, İbrahim. Eğitimin Oyunlaştırılmasına İlişkin Öğrenci Algıları: Bir Q Metodu Analizi. EĞİTIM VE BILIM, 2017, 42.191.

YILDIRIM, İ., DEMİR, S. (2016). Oyunlaştırma Temelli “Öğretim İlke ve Yöntemleri” Dersi Öğretim Programı Hakkında Öğrenci Görüşleri Students' Views about Gamification Based Curriculum for the Lesson of "Teaching Principles and Methods”. Uluslararası Eğitim Programları ve Öğretim Çalışmaları Dergisi, 2(6), 85-102.

Yin, R. K. (2011). Applications of case study research. London: Sage.

Yuksel, H.S. (2019). Experiences of Prospective Physical Education Teachers on Active Gaming within the Context of School-Based Physical Activity. European Journal of Educational Research, 8(1), 199-211. doi:10.12973/eu-jer.8.1.199

Yüksel H.S. (2018). Teknoloji Destekli Aktif Oyun Programına Katılan Ortaokul Öğrencilerinin Deneyimlerinin Incelenmesi. (Yayımlanmamış doktora tezi). Ankara Üniversitesi Sağlık Bilimleri Enstitüsü, Ankara.

Yüksel, H. S., Tuncel, F. (2017). Experiences of 5th Grade Students Participating in Active Gaming-Assisted Physical Education Lessons. Journal of Education and Training Studies, 5(13), 19-31. 